\title{
Extracting limestone: How to interpret the city through ammonites and belemnites
}

\section{Monika Sadowska}

(Faculty of Arts and Social Sciences; SWPS University of Social Sciences and Humanities) ORCID: 0000-0001-5025-2378

\begin{abstract}
The paper analyzes the presence of the remains of ammonites and belemnites in the stones used to build the elevations of houses in modern Polish cities. The process of aestheticizing buildings is the reason for fossilized cephalopods being moved from the natural environment into urban space. I consider whether the use of such materials leads merely to making the buildings look more attractive or if this process provides an opportunity to interpret these buildings in an alternative way, which goes beyond aesthetic categories and is related to the fact that the fossils have been moved from the natural world into the cultural sphere. The limestone elements of architecture also allow one to look at the city as a unique museum of cultural and natural history
\end{abstract}

Key words:

aestheticization, natural history, stone, city, museum

\section{Introduction}

The ground floor of an apartment building at ul. Dolna 11 in Warsaw is intended for shops and services. As of 2018, it houses a furniture store "Boutique Pierrot," a beauty salon "Euforia," and a dental clinic "Dolna Dent." The building, completed in 2005, is covered up to the first floor (and so also around the display windows of the premises) with limestone slabs containing ammonites that are a few centimeters across and slightly smaller belemnites. On each slab there are a few cephalopods, which are presented cross-sectioned along the shell so as to expose their inner structure. The building at ul. Dolna 11 is not an isolated case. Many apartment buildings intended for wealthy residents of big cities have their façades, floors, or stairways incorporate of various types of limestone slabs. 
The use of Upper Jurassic limestone (the one that usually contains fossils) in urban architecture is in no way a new practice. The geologist Jacek Rajchel, analyzing the buildings of Cracow, notes the following:

In the Romanesque period it [the limestone] was used most of all for the production of small brick-shaped blocks known as petit appareil, then in the Gothic period for the production of much bigger rectangular blocks-grand appareil. ... It was used for building portals, casings, columns, balustrades, posts, and flooring. Unrefined limestone blocks were used to build the defensive walls of Cracow and the Wawel and to pave streets and squares, including the main market square. (Rajchel 2007, 148)

Hence, it can be said that limestone had (and still has) an important influence on the appearance of European cities. ${ }^{1}$ To this day, several hundred different types of slabs cut from rock of calcareous origin (many of them containing ammonites and belemnites) circulate on the market, which might indicate the continuous popularity of this material among investors.

It is through the prism of these slabs and their fossils that I would like to examine the modern city. I will endeavor to determine whether the effect achieved with the use of these particular finishing materials merely makes the buildings look more attractive or if it also creates an opportunity to interpret the buildings in an alternative way, exceeding the category of beauty. In limestone blocks containing ammonites and belemnites, we look for interpretative possibilities, which can be created by elements of the natural world transferred to the world of culture. Since cephalopods belong to the animal kingdom, these opportunities seem to be related most of all to the scientific understanding of wildlife. Thus, I will try to reflect upon this perspective by analyzing the façade of a building as though it were a laboratory of sorts. What is more, by putting examples of limestone architectural elements of buildings in more metaphoric terms, I am searching for an opportunity, emerging under the gaze of an observant passer-by, to interpret the city as a museum of sorts. A museum that is different in the sense that it was created spontaneously and calls for special conditions of reception. Despite the barriers, I claim that this museum is democratized and free of any true constraints-a museum that exceeds the institution and evokes the history of prehistoric cephalopods.

\section{The elevation}

All three service outlets located on the ground floor of the building at ul. Dolna 11 are currently occupied by companies providing luxury services. These outlets are fashionably furnished and fitted with the newest equipment (according to the type

1 In a different book, Rajchel $(2009,314)$ indicates that limestone was a basic material used for building the structural elements and decorative features of architecture in Rome. 
of services provided). The aesthetics of their interior and exterior was probably already taken care of at the stage of drafting the architectural design of the building-after all, the way they look influences the price of the apartments in the building. The image of modern cities, created by architects building after building, led the philosopher Wolfgang Welsch to say that aestheticization is a common trend in urban planning.

Should one interpret the use of limestone blocks containing fossils in the finishing of modern buildings precisely in this way-as aestheticization? It seems that yes, one should, even if the architects' choice to use this material for elevations is likely also motivated by other factors, for instance by its practical qualities (wear resistance, endurance, etc.). Obviously, it is also a beautiful material, whose fine ammonite shells with their pleasant spiral shapes do not seem to be without significance for the decision to use this particular material.2 The fact that animal remains are built into the façades of houses (which probably would not be so willingly done if they were not prehistoric cephalopods but ordinary roof cats ${ }^{3}$ ) seems to give way to the impression of aesthetic satisfaction evoked by the textures and shapes of the extinct cephalopods. The limestone slab is perceived as aesthetic and the ammonite adds to its appeal, but can these animals really be considered beautiful? And if so, who is to judge?

The concept of animal aesthetics-referring to the discoveries of Charles Darwin, the father of the theory of evolution - has been studied by Welsch (2005), mentioned above. Darwin, as the philosopher recalls, when conducting observations of animal behavior (especially that of butterflies), reasoned that animals have a type of aesthetic sense, on the basis of which they are able to make an aesthetic assessment. This theory was not received enthusiastically by the scientific community of biologists, although, as Welsh points out, Darwin continued to defended it for as long as he could (he even referred back to it in his last lecture before his passing). The controversy around the animal aesthetic sense hypothesis probably follows from the fact that aesthetic assessments made by animals translate directly into sexual selection-namely, the choice of partner. If this choice is preceded by an aesthetic judgment, then in light of the survival of the species (which appears to be the primary goal of animals pairing off) it is clear that the aesthetic assessment must translate into an assessment of the partner's physical fitness-when choosing a partner, the female should pick the strongest male in order to ensure the survival of a the species. Seeing that she chooses the most attractive of them, it means that he is also the strongest. If this process is actually carried out in the manner described above,

2 Spiral shapes (e.g., a meander) were appreciated and used to decorate ceramic objects since ancieng Grece, cf. Press (1987).

3 It is probably worth mentioning another practice in which elements straight from the cemetery-though not remains but gravestones-were used as decorations. I am thinking here of a decorative pergola in "Leśnika" park in Warsaw, which was built from matzevahs. For more on this topic, see Baksik (2013). 
then the animal aesthetic assessment is not a measure of beauty but a measure of strength. Thus, evolutionarily developed peacock feathers are not beautiful; their purpose is not to delight but simply to attest to the male's health and strength. It was precisely against this reduction of beauty to fitness that Darwin, followed by Welsch, stood against. They both argued that animals can register beauty simply to admire it, not merely as a factor of fitness assessment.

Regardless of whether animals assess beauty for its own sake or in order to measure a partner's fitness, the very capacity for passing such judgment seems to be indisputable for both Darwin and Welsch. However, that does not mean that this is true for all animals. Darwin noted that the sense of taste (the ability to notice and valorize beauty, which is under discussion here) is being formed in the course of evolution. According to Darwin, ammonites, belemnites, and other animals of the Upper Jurassic period, as animals evolutionarily underdeveloped, do not possess this sense. The shape of their body does not play any role in the process of sexual selection; it does not represent their fitness nor beauty. The appearance of these animals does not constitute a response to any drive; the aesthetic assessment does not apply to them. Welsch notes that:

For Darwin, not every kind of beauty is a product of aesthetic correlation and coevolution. Two incipient types of beauty emerged in evolution long before an aesthetic sense developed. The first one is found in "low animals" like corals, sea-anemones, or some jelly-fish that "are ornamented with the most brilliant tints, or are shaded and striped in an elegant manner.." Darwin explains this pre-aesthetic type of beauty as "the direct result either of the chemical nature or the minute structure of their tissues.." Such beauty just happened to arise as a physiological effect, without the implication of any aesthetic function. Only after the development of an aesthetic sense could such pre-aesthetic beauty be esteemed as beautiful. Originally it was not an aesthetic matter at all. (Welsch 2004)

If Darwin was right, the beauty of ammonites emerged only about 190 thousand years ago, along with the appearance of the first man on Earth (homo sapiens), who could admire them. It was a man who (using his aesthetic assessment) valorized the ammonite as beautiful. This type of assessment had not existed before. Thus, for sixty-five million eight hundred and ten thousand years the ammonite was a representative of beauty beyond aesthetics, of beauty in a form preceding the concept itself. Hence, it is interesting that limestone, a material containing these particular animals, serves as a tool for the aestheticization of our homes. Do the remains of these animals represent a different dimension of beauty (which was created without a purpose and could not have been appreciated by anyone else except us)? And maybe now, when we (as humans) have at our disposal not only aesthetic judgment but also scientific knowledge, the beauty of the ammonite can play more 
than just one role? These questions are worth asking, treating them as a starting point for extended research concerning the presence of animal remains in cities, research that is certainly worth conducting.

Referring to these issues, I propose two possible interpretations of ammonites and belemnites embedded in the elevations of buildings-namely, as objects in a unique laboratory and as exhibits in an alternative museum. I believe that these two ways of interpreting these exceptional elements of aestheticization of cities bring forward the potential hidden in cephalopods visible in elevations. In my opinion, this potential can be expressed both in scientific knowledge and in evoking anew the history of these prehistoric animals.

\section{Laboratory}

The Polish Geological Institute is less than two kilometers from ul. Dolna 11, at ul. Rakowiecka 4 in Warsaw. On its fence, there is a large format picture of an ammonite on display. This picture does not perform an aesthetic function; it presents a scientific object, the description of which is a result of the work done by scientists employed at the institute. The poster format brings pedestrians closer to what happens behind the closed doors of the research center every day.

This short distance between the ammonites as objects of research, located in the building on ul. Rakowiecka, and those embedded in the elevation of the apartment building on ul. Dolna, which are perhaps admired by the residents of Sielce, seems to draw a metaphorical line between the often negatively perceived aestheticized city, as a space that offers mainly commercial entertainment, ${ }^{4}$ and the temple of science, a place dedicated to the production of knowledge about the world, a serious research center, perceived as an institutional machine for producing the truth. However, can you only learn something about these animals on ul. Rakowiecka, as a member of a small group of scientists with access to prehistoric cephalopods? Does the laboratory, in which phenomena of the physical world are studied, have to be located in a separate, closed space? A study carried out by Scott P. Hippensteel, a geologist from the US, seems to be an interesting example of defying the belief that knowledge should be produced "behind closed doors," not in public places, as he decided to treat the shopping mall and the airport as the areas of his research.

Hippensteel, working at the University of South Carolina, conducted studies in a series of articles on the taxonomy of ammonites and belemnites that consisted of verifying floor tiles used in the SouthPark Mall and at the Orlando International Airport. First, he identified tiles containing fossils, then he narrowed down the scope of the study to those tiles with fossils of more than one animal (which allowed for an analysis of their origin and history, for example when it comes to the processes

4 I am referring here to the concept of urban anesthetics, in which aestheticization of public space leads to the production of a beautiful pretense. See Zeidler-Janiszewska (1999). 
of dead ammonites and belemnites drifting through currents) (Hippensteel 2015). Hippensteel, in order to conduct his research, decided to transform the shopping mall and the airport into "field laboratories"5. The father of microbiology and the founder of the first non-institutional laboratory-Louis Pasteur, whose actions were reflected upon by philosopher Bruno Latour (1983) - did something similar. Hippensteel, like Pasteur, decided to go beyond the bounds of the research institute and to move his laboratory to a place where he could come into contact with his object of study. The obvious difference is that, unlike the anthrax studied by Pasteur, the ammonites analyzed by Hippensteel do not endemically occur where he conducted his research. Ammonites and belemnites probably found their way to the floors of the shopping mall and the airport-as Hippensteel established-from Italy. And they reached the Italian Peninsula from Germany, or to be more precise, from Upper Bavaria. Pasteur could observe anthrax in its "natural environment" (the possibility of conducting that observation became the primary reason for the establishment of the first field laboratory), whereas Hippensteel, having no access to a quarry in Germany, had to limit his research to what was transported from there. ${ }^{6}$ The thousands of kilometers separating ammonites in situ from those available to Hippensteel have a significant impact on both the methodology of the study (in order to conduct the analysis the scientist had to find tiles with at least two animals) and its possible conclusions. Despite those limitations, Hippensteel's study was successful and resulted in several publications in geological journals.

What enabled Hippensteel's work was the process of aestheticization, thanks to which limestone slabs were transported thousands of kilometers from the place where they were cut from the rock. Without moving the material in order to decorate the shopping mall and the airport, the scientist would not have had such (Bavarian)

5 We do not need to see Hippensteel's work at the airport and in the mall as setting up a field laboratory, instead we can perceive it as a field work similar to what is done at geological positions. It seems, however, that a broader view of the scientist's activities, i.e. perceiving it as establishing a laboratory-satellite, may also be justified. During his stay in selected places, Hippensteel performs a series of translations, for example, selecting for further analysis only those tiles that contain the most interesting arrangement of ammonite skeletons in terms of possible conclusions. The material narrowing process helps him to draw conclusions of a much broader scope. Bruno Latour in his classic text "Give me a laboratory and I will move the world” indicates the processes of reducing and enlarging as those that take place in the laboratory. For this reason, I believe that Hippensteel's actions at the airport can be considered as establishing a field laboratory. Of course, these premises may prove to be insufficient. In addition to reducing and enlarging, Latour also points to such processes taking place in the laboratory as establishing a network of political relations with other research stakeholders, or conducting experiments with numerous setbacks and subsequent attempts. Unfortunately, it is not clear from the materials to which I have access whether the management of the airport and shopping center knew about the researcher's study and whether any relationship was established. One can only guess that without a conversation between the scientist and the managers of these institutions, the study would not have been possible. Limited access to information, however, does not allow me to state it with certainty, and thus clearly state that Hippensteel actually founded something like a field laboratory. For this reason, I use this term in quotation marks in this article.

6 It might be worth noting that although Pasteur studied anthrax in its natural environment, it was neither the first nor the only focus of the infection. In this sense, he also dealt with a depleted sample of the bacteria (its other mutations could have occurred elsewhere, etc.). 
specimens of ammonites and belemnites at his disposal, and perhaps (without applying for additional grants for research trips) would never even have come across these particular specimens of prehistoric animals. Therefore, the knowledge that he acquired on the basis of his research could have never been produced. In this case, the processes of the aestheticization of the city (with the use of limestone slabs) had a positive effect on the possibility of learning about cephalopods.

As I wrote earlier, Hippensteel's study was limited (though not that much, as the airport floor was over $200,000 \mathrm{~m}^{2}$ ), which certainly affected the final results. However, it is not the case that studying a limited number of specimens taken out of their "natural environment," especially when it comes to geological research, is novel to the scientists working in this field. Józef Siemiradzki, a distinguished Polish geologist and traveler, in the introduction to the study of taxonomy of cephalopods found in the Polish mountains, published in 1891, writes as follows:

Over the last few years, I myself have been gathering Upper Jurassic fauna material; apart from that, Dr. Zaręczny gave me his own collection to study, and Dr. Rostafiński entrusted me with the rich collection of the Physiographic Commission. As a result, I have ample material-it includes more than 130 forms of cephalopods, and several thousand specimens from other sections of the animal world. ... However, this list of cephalopods is not yet exhaustive; I know of the existence of some undefined forms, for the description of which I do not have enough data, for instance in the collection of prof. Roemer in Wrocław, there is an interesting ammonite he styled as Amm. czenstochoviensis which is, as far as I can tell after seeing the original specimen, an unknown form of Quenstedticeras or Cadoceras. In this collection there is an ammonite from the virgulata group, unknown to me from other collections, that comes from the area of Częstochowa. Finally, there are several unlabeled specimens in the studied collections, which do not belong to any of the labeled forms. There is also a rich collection of Hohenegger in Munich, not at all developed, which may contain something new belonging to this fauna. The same applies to Michalski's collection at the Saint Petersburg Akamedia Górnicza [Mining Academy], the collection of prof. Bieniasza, the Viennese collections, and finally the inaccessible though ample collections of Muzeum Dzieduszyckich [the Dzieduszycki Museum] in Lviv. (Siemiradzki 1891, 1-2)

Hence, Siemiradzki's research was based on private collections, sometimes constructed not by scientists but by amateur collectors. One could infer that new specimens, including unlabeled ammonites and belemnites, were added to these collections often quite spontaneously; the choice of these particular specimens might not have been dictated by the intention of broadening scientific knowledge on cephalopods, but rather by a desire to own amazing exhibits.

Twenty years after the publication of the words quoted above, Siemiradzki managed to access the collection of the Dzieduszycki Museum in Lviv. He examined the 
collection that was made available to him and then published the taxonomy of the studied animals in his Geologia ziem polskich (The Geology of Polish Lands). In the foreword to the first volume he wrote the following: "Some chapters were written based almost exclusively on the materials owned by this Museum" (Siemiradzki 1903). Hence, there is no doubt here that collections created without scientific purposes in mind can become the basis for the production of scientific knowledge.

The circumstances of Siemiradzki's and Hippensteel's research are similar in the sense that both scientists worked with objects that had not been selected by them beforehand-they had no influence on the collections that were at their disposal, and they were probably unaware of the circumstances surrounding the gathering of the material. At the same time, what should be stressed is that both studies differed significantly. The Polish geologist struggled mainly with institutions making the specimens inaccessible to scientists, with the "musealization" of objects of research and their being treated almost like works of art. The American scientist, on the other hand, did not have any problems with reaching the selected specimens (although it is probably worth reflecting on whether the ammonites used as the airport floor, through exposure in a public space, had not become practically invisible, similarly inaccessible, just like those under lock and key). In both cases, studying cephalopods required some scientific courage and passion. Going beyond a research center, Siemiradzki examined a non-scientific museum collection, while Hippensteel produced scientific knowledge based on decorative elements of buildings. In this way, they both reached specimens that were unknown to them up to that point.

When reflecting upon the "field laboratories" established by Hippensteel, it can be noted that they shifted the role of a limestone slab from being a decorative element, subject to aesthetic judgment, towards being a scientific object, a valorized taxonomical description of specimens. In this way, these "laboratories" have redefined the role of limestone slabs in cities. According to this new approach, the limestone elevation ceases to be merely an element in creating the aesthetic appearance of a modern city. A non-aesthetic ammonite, embedded in it, remains an animal that can be described and examined. Thanks to treating the elevation as a geological "field laboratory" or at least a geological site the ammonite escapes aesthetic judgment, and it transforms the limestone slab, indicating a different potential. The use of this material ceases to be solely an act of urban aestheticization and becomes an opportunity to learn about nature. An opportunity that arose spontaneously, without a predetermined aim, but also an opportunity that is available due to the process of aestheticization. Thus, the city becomes a sprawling geological site, a place that offers specimens that might otherwise be unavailable to scientists in their institutes. ${ }^{\text {? }}$

7 It is worth adding that perceiving a city as a geological laboratory also allows us to exceed the metaphor of a city as a laboratory for social studies. For more information on this second approach, see Rewers (2014). 


\section{Museum}

Open access to specimens, especially those located in crowded places, such as airports, shopping malls, and those visible on the elevations of buildings in urban spaces (returning again to ul. Dolna 11), creates opportunities not only for a scientist searching for research material, but also for someone who just happens to be walking by and notices them. Placing fossils in open spaces democratizes access to them. They are now practically at one's fingertips for anyone who wants to see them. From this perspective, for a few observant passers-by, one could say for modern flâneurs, the city and its decorative elements can be interpreted as a kind of exhibition.

I reach for the figure of an urban saunterer, a flâneur, because they represent a particular attitude. In the approach presented by the philosopher Walter Benjamin, it coincides with the attitude of a child discovering the world, who through natural curiosity is able to notice that which remains hidden from others. Beata Frydryczak, a cultural theorist, writes as follows:

The child's goal ... is not "keeping new things new, but renewing that which is old." That renewal is to absorb that which has been found. Those things, "purified," devoid of their original meaning and functions, hold only a subjective meaning however newly assigned. Children do not merely look at them with their probing and refreshing gaze, noticing something new in objects, but also use them in a creative way. ... This creative attitude makes it possible to restore the objects to their proper place in the order of the world. (Frydryczak 2002, 199)

This child-like attitude, characteristic of those who love walking around the city, allows them to notice and reconceptualize the decorative limestone slabs encountered on buildings. However, it is no longer just aesthetic fascination or pure scientific cognition. Flâneurs, when admiring an encountered object, combine those two perspectives; they "restore objects to their proper place in the order of the world" by restoring ammonites and belemnites to their rightful place in history, evoking it anew. Is it then possible to say that an elevation stone, in which a flâneur is able to notice specimens of fossilized ammonites and belemnites, can turn a city into a museum?

When we think of a city as a museum, the metaphor most often takes the shape of a historical museum or an art museum (depending on what measure we apply to the objects located there). An obvious example of such a city is Rome, which can certainly be seen as an art museum. This interpretation becomes especially clear when we take into account the art, publicly available in Rome, that comes from Egypt, the Black Sea, and the southern regions of Italy, which were plundered by the Romans between the $4^{\text {th }}$ and the 1st century BC (Bergman 1995, 87). The Roman 
art collection can be admired in the public space of the Italian capital at almost every turn. However, Rome is not the only example of a city-museum.

A different Italian city, Florence, can serve as another example (this time an example that exceeds what we might now call a colonial heritage). As early as 1862 , the Polish librarian Michał Wiszniewski reported: "Through the blissful times of the Medici, Florence became so rich in fine arts that they were almost pouring out into the streets, and the entire city was transformed into a magnificent museum" (Quoted in Wrześniak 2013, 300). Hence, great Italian cities certainly had (and still have) the potential to be perceived as museums. One can look similarly at Cracow, already mentioned in this paper, which can be seen not only through the prism of an art museum, but also a kind of a geological museum.

Majer-Durman, in the introduction to an article in which she maps out a tourist route around Cracow following different varieties of limestones used as architectural elements of buildings, ${ }^{8}$ writes the following: "When starting an adventure with culture and monuments, it is worth visiting places where Upper Jurassic limestone is found and used in architecture, as it is one of the most commonly exploited natural stones in the Cracow area" (Majer-Durman 2012, 19). The author, justifying this unusual route for visiting Cracow, conducted a survey among the residents of the city asking them about their knowledge of the materials used for its construction and their willingness to participate in city tours with a geologist. The survey revealed that unveiling the geological dimension of the structural elements and elevations of the grandest buildings in the city (including the Collegium Maius, decorated with ammonites) meets the interest and the demand of the residents of Cracow.

When it comes to the possibilities for contact between the audience and the limestone in Cracow, it seems, however, that the route proposed by Majer-Durman could be extended. Limestone is not (and was not) used only as an element of Cracow's architectural exteriors, but also as an element of interior design and as a medium for works of art. Rajchel, tracking a specific type of limestone in Cracow, namely travertine, writes as follows:

Travertine from the Silesian-Cracow monocline was used mainly in sacral-sepulchral art. At the beginning of the 2oth century, rough, untreated, and sometimes large lumps of this travertine were used for making tombstones, especially in the older part of the Rakowicki cemetery. A good example of this practice is a tombstone depicting a crying woman under a cross, located about $50 \mathrm{~m}$ to the right of the main entrance. (Rajchel 2009, 316)

8 The route proposed by Majer-Durman is $12 \mathrm{~km}$ long and passes through the Zakrzówek quarry, the Liban quarry, the Pod św. Benedyktem quarry, the Szkoła Twardowskiego quarry, past limestone pavement around the church of St. Giles, the buttresses of the Franciscan Fathers Church, Collegium Maius-the buttresses and the elevation (containing ammonites), the columns in the chapel of St. John Cantius in the collegiate church of St. Anna, and the walls of St. Florian's Gate. 
Further, in the same text, the geologist also notes:

Daino Reale [a type of Italian travertine] is the best preserved stone in terms of stromatolite and oncoid structures of all the architecturally used travertines in Cracow. ... This travertine contains ... shells of snails, visible in the longitudinal and cross sections. The shells of these mollusks are best preserved in the counter top of the reception desk and in the fireplace frame of the Maltański Hotel at ul. Straszewskiego 14, in the table tops of the Copernicus restaurant at ul. Kanoniczna 16, as well as in the elements of the fountain in Galeria Kazimierz [a shopping mall] at ul. Podgórska 34. (Ibidem, 317)

Thus, the concept of the curated tour around the city, as if it were a geological museum, finds justification in the abundance of specimens, which can be seen on buildings and artifacts in Cracow's urban space. The city therefore offers equal, open access to collections, and their spontaneous selection affords finding truly unique specimens.

The sociologist Marek Krajewski sees in such democratized and spontaneously created museums an opportunity - a contribution to a significant change, which traditional museums could undergo in order to better fulfill their role, adapting to the modern realities of life in highly developed societies.

\begin{abstract}
The basic measure leading to this goal, the prototypes of which have already been created and tested, is the democratization of access to museums for the public and recognizing them as active creators rather than passive recipients. The implementation of this task requires noticing creativity where, at first glance, it isn't found-in the everyday practices of individuals trying to adapt to reality. For the ever changing and unstable context of our daily lives requires not only courage, but also imagination, both necessary not only to survive, but also to defend our individuality. (Krajewski 2007, 59)
\end{abstract}

For Krajewski, the ideal objects in new museums would be "wonderfully" decorated balconies or urban flowerbeds made of recycled tires or pallets-anything that results from the creative work of individuals in a city. When considering the objects suggested by the sociologist and comparing them to limestone elevation slabs, it is not difficult to see that they are objects and places created through grass roots initiatives, undertaken by people who are much less specialized than experienced architects, who are in turn the ones prompting the use of the elevation materials discussed here. They are also much less expensive than covering an apartment building with Upper Jurassic limestone. However, can we not interpret this process (due to the problems listed above) as the "everyday practice of individuals trying to adapt to reality"? Well, perhaps this practice, related to creating an impression of exclusiveness, is slightly less "everyday" than those listed by Krajewski; however, in a way it still seems habitual, automatic, and obvious (especially in the process 
of aestheticization of big cities). Is the concept of a democratized museum not precisely about seeing the positive potential in the unconscious processes of culture? Is it not a watchful eye that is able to find value (aesthetic value, related to scientific cognition) in something boring, monotonous, and ordinary, that has the power to transform reality? Adopting such a perspective in the process of aestheticizing the city allows one to notice the potential for creating a new museum-a museum that is open, but requires the visitors to be creative in seeing, a museum located in a city that offers to familiarize one with nature.

\section{Conclusions}

In this paper I have tried to take a closer look at the limestone slabs decorating urban buildings and at the remains of the ammonites and belemnites contained in them. The process of aestheticizing buildings is the reason for fossilized cephalopods being moved from the natural environment into urban space; however, that does not mean that Upper Jurassic limestone, which contains these animals, cannot perform functions going beyond this process. The limestone slabs discussed here do not perform a solely decorative function; when analyzed from different perspectives, they can reveal further possibilities of interpretation.

Going beyond the perspective of modern humanities, a perspective that is based on the evaluation of the processes of city aestheticization from a social point of view, we can find their positive potential. The city does not have to be merely the subject of studies conducted by historians or sociologists; it can also be an arena for the production and transfer of geological knowledge. The process of transferring the elements of nature into cities can ultimately be extremely significant for the natural sciences. Such initiatives may contribute to the identification of new species, and they may also become a pretext for restoring the memory of longextinct animals.

Nature and culture intertwine in cities in many ways. Thanks to reflection on this intertwining, the city can become a space that is understood beyond the assessment of social processes, a space that is used as a laboratory or a museum; it can also reveal further possibilities of interpretation, for geology is not the only science for which the elements of the city may display positive potential. The search for that potential remains an open project.

\section{References}

Baksik, Łukasz. 2013. Macewy codziennego użytku [Matzevahs of Everyday Use]. Wołowiec: Wydawnictwo Czarne.

Bergmann, Bettina, 1995. "Greek Masterpieces and Roman Recreative Fictions." Harvard Studies in Classical Philology 97: 89-120. 
Frydryczak, Beata. 2002. Świat jako kolekcja. Próba analizy estetycznej natury nowoczesności [The World as a Collection: An attempt to analyze the aesthetic nature of modernity]. Poznań: Wydawnictwo Fundacji Humaniora.

Hippensteel, Scott P. 2015. "Fossil Belemnites and Ammonites from a common decorative stone used throughout the Southeast: Jura Limestone," Southeastern geology 3 (51): 121-28.

Krajewski, Marek. 2007. "Od muzeum publicznego do muzeum publiczności" [From a public museum to a museum of the public]. In Muzeum jako świetlany przedmiot pożądania, edited by Jarosław Lubiak, 51-76. Łódź: Muzeum Sztuki.

Latour, Bruno. 1983. "Give me a Laboratory and I will Raise the World." In Science Observed: Perspectives on the Social Study of Science, edited by Karin Knorr-Cetina and Michael Mulkay, 141-69. London: Sage.

Majer-Durman, Agnieszka. 2012. "Występowanie wapieni górnej jury na terenie Krakowa i przykłady ich wykorzystania w architekturze miasta" [Instances of Upper Jurassic limestone around Cracow and examples of its use in the city architecture]. Geoturystyka 1-2 (28-29): 13-22.

Press, Ludwika. 1987. "Spirala, meander i rozeta w sztuce trackiej i egejskiej" [Spiral, meander, and rose patterns in Thracian and Aegean art]. Studia i materiaty archeologiczne 6: 75-91.

Rajchel, Jacek. 2007. "Z czego Kraków budowano" [What Cracow was built of]. Wszechświat 108 (4-6): 147-50.

Rajchel, Jacek. 2009. "Martwice wapienne w architekturze Krakowa" [Travertine in the Architecture of Cracow]. Geologia 35 (2/1): 313-21.

Rewers, Ewa, ed. 2014. Kulturowe studia miejskie [Cultural Urban Studies]. Warszawa: Narodowe Centrum Kultury

Siemiradzki, Józef. 1891. Fauna kopalna warstw oxfordzkich i kimerydzkich w okręgu krakowskim i przylegtych częściach Królestwa Polskiego. Część I. Gtowonogi [Fossils of the Oxfordian and Kimmeridgian Layers in the Cracow region and the surrounding areas of the Kingdom of Poland: Part l; Cephalopods]. Kraków: Drukarnia Uniwersytetu Jagiellońskiego.

Siemiradzki, Józef. 1903. Geologia ziem polskich. Formacje starsze do jurajskiej włącznie, Tom I [The Geology of Polish lands. Vol. 1, Older formations including the Jurassic]. Lviv: Muzeum im. Dzieduszyckich.

Welsch, Wolfgang. 2004. "Animal Aesthetics." Contemporary Aesthetics 2. https://www.contempaesthetics.org/newvolume/pages/article. php?articlelD $=243$.

Welsch, Wolfgang. 2005. Estetyka poza estetyką [Aesthetics Beyond Aesthetics]. Translated by Katarzyna Guczalska. Kraków: Universitas. [German original: Grenzgänge der Aesthetik, Stuttgart: Reclam, 1996]

Wrześniak, Małgorzata. 2013. Florencja—muzeum. Miasto i jego sztuka w oczach polskich podróżników [Florence-Museum: The city and its art in the eyes of Polish travelers]. Kraków: Universitas.

Zeidler-Janiszewska, Anna. 1999. "O anestetyzacyjnych akcentach w tak zwanej sztuce publicznej" [On anaestheticizing accents in so-called public art]. Kultura wspótczesna 2: 77-85. 